\title{
Corporate Governance and Performance: An Empirical Investigation of Sugar Producing Companies in Kenya
}

\author{
Machuki, V.N. (PhD) \\ School of business, University of Nairobi, Kenya \\ Rasowo, J.O. (PhD) \\ Technical University of Mombasa, Kenya
}

Doi:10.19044/esj.2018.v14n31p240 URL:http://dx.doi.org/10.19044/esj.2018.v14n31p240

\begin{abstract}
Corporate governance is concerned with the running of an organization in a way that guarantees that its owners or stockholders receive a fair return on their investments while the expectations of other stakeholders are also met. The study sought to examine the relationship between corporate governance practices and performance of sugar producing companies in Kenya. The study intended to establish the corporate governance practices adopted by the companies and the influence of these practices on their performance. Through a cross-sectional survey of 11 companies, data were gathered using a structured questionnaire and analyzed using both descriptive and inferential statistics. The results indicate that all the studied companies practice some form of corporate governance although the degree of adoption differ across them. The study also revealed that board decisions are not influenced by founder members and that it was not common for board members to engage in financial transactions with the companies. The results of regression analysis show that overall, there is a positive and statistically significant influence of corporate governance practices on performance of the sugar producing companies. The study draws a conclusion that a combination of good corporate governance practices is responsible for a large percentage of good performance achieved by the sugar companies. Individual corporate governance practices acting on their own do not always lead to improved performance. The study offers support for theories that anchor performance implications of good corporate governance as well as findings of previous similar studies. Based on the findings of the study, recommendation for policy and practice are made as well as suggestions for further research.
\end{abstract}

Keywords: Corporate Governance, Organizational Performance, Sugar Processing Companies 


\section{Introduction}

Governance is all about structures and processes for control, decision making, accountability, and behavior at the top of organizations. Owners (shareholders) of a firm have a claim on the firms' net income and as a consequence their interest is in greater net income and profit. Owners cede control of the organization to professional managers as business grows. Further growth creates the need for cheaper additional funds from a variety of sources, hence a move from shareholders to stakeholders (Machuki and Oketch, 2013). Hired managers have no inherent interest in the organizations profit since they belong to the owners, but their behavior affects profit. This creates the agency problem since the managers' incentives are not aligned with those of the owners and shareholders.

Corporate governance is concerned with the running of an organization in a way that guarantees that its owners or stockholders receive a fair return on their investments while the expectations of other stake holders are also met. Mallin (2010) points out that corporate governance is in the limelight due to the demand by stakeholders for accountability and transparency in light of the global financial crisis, corporate scandals and company collapses.

Defining the concept of corporate governance in a universally acceptable way is difficult with definitions varying from country to country (Mulili and Wong, 2011). A fairly narrow definition of corporate governance is given by Shleifer and Vishny (1997) in terms of the way in which suppliers of finance to a firm assure themselves of a good return to their investment. The Australian Standard (2003) defines corporate governance as the process by which organizations are directed, controlled, and held accountable while Cadburry (2000) defines corporate governance as a systems by which firms are directed and controlled.

A broader definition is provided by the Organization for Economic Cooperation and Development (OECD) (OECD ,1999), which describes corporate governance as a set of relationships between a company's board, its shareholders and other stakeholders. According to OECD, the corporate governance structure specifies the distribution of rights and responsibilities among different participants, such as the board of directors, managers, shareholders and other stakeholders, and spell out the rules and procedures for making decisions on corporate affairs. By doing this, it also provides the structure through which organizational objectives are set, and the means of attaining these objectives and monitoring performance (Machuki and Oketch, 2013). The King Commission on Corporate governance (Kings Commission, 2002) in South Africa advocated for an integrated approach to good governance in the interest of a wide range of stakeholders, having regard to the fundamental principles of good financial, social, ethical, and environmental practice. The Kenya Private Sector Governance Trust (1999) defined 
governance as the manner in which power is exercised in the management of economic and social resources for sustainable human development. Our study will adopt both the Kings Commission and the OECD definitions of corporate governance (Kings Commission 2002; OECD,1999).

Good corporate governance is applicable to all organizations: for profit, private, public, not-for-profit, small, medium, and large in order to ensure that organizational goals and missions are realized through good stewardship of resources (Machuki and Oketch, 2013). In addition, we need to take cognisance of the fact that organizations operate in complex and dynamic business environments that require complex but flexible governance regulation reflecting the uniqueness of each situation arising from specific factors such as legal and financial systems, culture, corporate ownership structures and economic conditions (Onyango, 2009). No single set of governance rules fits all firms and situations and thus governance should be understood in different contexts. In for profit organizations, shareholders incur agency costs (Jensen and Meckling,1976) including monitoring, bonding and residual losses to control activities of managers. Agency contracts provide for performance related financial rewards to encourage managers to act in the interest of shareholders. Tools used to enforce accountability include performance assessment, evaluation, reporting requirements, laws and self regulation. Governance provides the structure through which the company objectives are set, the means of attaining those objectives and monitoring performance (Dezoort et al, 2002).

Organizational performance comprises the actual output or results of an organization whereby they quantify the efficiency and effectiveness of their actions, decisions and operations as measured against its intended goals and objectives as per the strategic plans (Neely, Platts \& Gregory, 2005). The way management and control are organized affects the company's performance and its long term competitiveness. Indeed there is strong evidence pointing to a positive association between corporate governance and organizational performance (Love, 2011).

Performance is a contextual concept associated with the phenomenon being studied (Hoffer 1983). Barney (2001) postulates that the concept of organizational performance is based upon the idea that an organization is a voluntary association of productive assets, including human, physical, and capital resources, for the purpose of achieving a shared purpose. Those providing the assets will only commit them to the organization as long as they are satisfied with the value they receive in exchange, relative to alternative uses of the assets. As a consequence, the essence of performance is the creation of value. Value may be tangible or intangible, operational, or financial (Vafaes, 1999). Performance is therefore a multidimensional construct which permits value to be created on different dimensions. This fact is supported by the 
number of different dependent measures that have been used to rate organizational performance in research studies (Murphy et al 1996). The most common approach has been to look at three areas of organizational outcomes namely: financial performance (profits, return on assets, return on investment); product market performance (sales, market share) and shareholder return (total shareholder return, economic value added) (Decoene and Bruggenman, 2006). The study adopted the balanced scorecard (BSC) as put forth by Kaplan and Norton (1992) to measure performance. The scorecard allows measurement of performance to capture both financial and non-financial performance as depicted by the four perspectives (financial, customer focus, internal business processes, and learning and growth).

The sugar subsector in Kenya is facing several challenges. The ownership of the companies is complex consisting of private owners/family owned firms, government owned (parastatal), and corporations This has resulted in disparities in level of performance with some barely surviving, some being under receivership while others doing very well and quoted in the Nairobi stock exchange. In addition, the sugar industry in Kenya experiences the problem of high cost of production and global competition from other sugar producers. Kenya's sugar prices are higher than not only Brazil but also the neighboring countries of Zambia and Malawi yet the geographical and climatic conditions in the two countries is the same (Ophelie, 2006). Good corporate governance has been shown to have a positive effect on firm performance and thus this research proposal is informed by the gap that exists between performance of the sugar industry and implementation of good corporate governance.

Numerous studies have analyzed the relationship between corporate governance and firm performance. The studies have explored the impact of various aspects of corporate governance such as composition and size of boards, frequency of board meetings (board activity), number of directorships (board busyness), CEO-Chair duality, and ownership structure on firm performance. The results of the studies have established that the corporate governance structures adopted strongly influences firm performance with good corporate governance affecting performance in a positive way (Agrawal and Knoeber, 2012). Machuki and Oketch (2013) examined the relationship between corporate governance structures and performance of HIV/AIDS NonGovernmental organizations and concluded that corporate governance is important and responsible for a large proportion of the good performance achieved.

Several empirical studies in Kenya have focused on corporate governance and financial performance of firms drawn from the private sector, local authorities, and the agricultural sector (Awino, 2009; Abwoga, 2001; Gicheru,2007; Kemei, 2010; Kitetei, 2009;Maina 2009; Ombayo, 1999; 
Onzare, 2008; Murage, 2008; Njoka, 2008) and all have established that there is a relationship between firm performance and frequency of board meetings, board size, the ratio of outside directors to total directors, and the percentage of insider share ownership and executive compensation. A study by Gathura (2007) seeking to determine the relationship between various components of corporate governance and financial performance of manufacturing firms listed in the NSE revealed a linear relationship between performance, frequency of board meetings, CEO compensation and board compensation. Kiamba (2008) in a study to determine the effect of corporate governance on financial performance of Local Authorities in Kenya reported that the financial performance was influenced by their political composition, the manner in which internal audits were conducted, and the managerial approaches applied by the chief officers.

In a study of the sugar subsector, Ondiek, Kisombe and, Magutu (2013) examined the extent to which lean operation tools and techniques are adopted by sugar industries in Kenya and their impact on factory time efficiency. They concluded that the sugar sector in Kenya has not fully implemented practices associated with these techniques. There has been very little research on the relationship between corporate governance and performance of sugar industries in Kenya. This study sought to find out if there is any correlation between corporate governance and performance of sugar firms in Kenya. The main objectives of the study were to establish the corporate governance practices in the sugar producing companies in Kenya and to determine the influence of the corporate governance practices on the organizational performance of sugar producing companies in Kenya.

The findings of this study are of great importance in theory building as it adds to the body of knowledge on corporate governance best practices particularly with regard to its effects on organizational performance. The results are pointing to the fact that independent corporate governance practices have less effect on organizational performance as compared to their combined effects. Furthermore, the results of this study are of value to policy development and managerial practice. The findings highlight the importance of board establishment and board functions, board meetings, board structure, regulatory frameworks as well as the CEO on the performance of the sugar firms. This should inform policy on appointment of boards including mandatory induction of the boards on first, appointment. Internalizing the managerial practice of always using the code of best corporate governance practice, if cascaded to firms in other sectors of the Kenyan economy, will assist steer the country towards the achievement of Vision 2030. 


\section{Literature Review}

Corporate governance is a system of processes leading to organizational responsibility to the shareholders and other stakeholders. However, in order to grasp a clear understanding of corporate governance, one needs to understand a number of theories that attempt to explain the basis and rationale behind this management imperative. These theories explain the nature of the relationship in organizations and how these relationships can be managed within internally generated policies and externally imposed rules and regulations to achieve the intended performance goals and objective (Mallin, 2010). In this regard, corporate governance is anchored in agency theory (Jensen and Meckling, 1976), stakeholder theory (Freeman, 1984), stewardship theory (Donaldson and Davis, 1994), and resource dependence theory (Aldrich and Pfeffer, 1976; Pfeffer and Salancik, 1978).

Agency theory views an organization in regard to the relationship between the principal (owners), who delegate decision making power to an agent (managers). The principals have neither the requisite expertise nor the time to effectively run the firm and therefore hand them over to the agents for control and day-to-day operations.. Under agency theory, managers should only be concerned with shareholders interests when making decisions. However, managers are also presumed to be inclined to make decisions that increase their influence and power, ignoring the interests of the shareholders (Machuki and Oketch, 2013). Agency problems arise whenever investment ideas and preferences of principals are at variance with those of the agents (Ongore and K'Obonyo, 2011). Consequently, owners incur agency costs such as bonus payment and audits to monitor managers. The board of directors act as the intermediary between the principals and their agents, and is charged with the responsibilities of leadership, stewardship, monitoring, and reporting back to principals (Thakkar, 2007; Ongore and K'Obonyo, 2011).

The stakeholder theory proposes that companies should serve the interests of a number of groups, not only that of shareholders. This approach is broad since it articulates management policies and attends to diverse stakeholders (Machuki and Oketch, 2013). Accordingly, organizations should acknowledge their legal and moral obligations to all legitimate stakeholders, both internal and external, individual and group, institutional or otherwise.

The stewardship theory provides that managers should diligently apply resources to achieve higher profits and maximum shareholders returns. It argues that managers are not only self interested but are also capable of positive actions; they have a need for achievement and internal satisfaction, and will improve their performance in their role as stewards of organizational resources to meet these needs (Machuki and Oketch, 2013).

The resource dependence theory holds that firms can earn good returns if they have superior intangible resources (Miller, 2003). These valuable 
resources become a source of sustained competitive advantage when they are neither perfectly imitable nor substitutable without great effort (Miller, 2003). According to this theory, organizations are not able to internally generate all the resources or functions required to maintain themselves, they must therefore develop relationships with elements in the outside environment to obtain the required resources and services (Conner and Prahalad, 1996). Internal systems that satisfy the demands of both internal and external resource providers must therefore be put in place. Consequently, resources give organizations power, which changes relationships by prioritizing shareholders interests, working towards increasing their value and revising compensation practices to improve performance and share price (Machuki and Oketch, 2013).

From the foregoing theoretical underpinnings, it is clear that governance mechanisms seek to protect the interest of all stakeholders of a firm. The import of corporate governance is to ensure the separation of control and management of the organization. This is made possible through the corporate governance structures. These structures exist in an organization to set the vision and direction and secure necessary resources, monitor activities to ensure they are working towards the vision, and ensure the organization is accountable in using resources, report to stakeholders and meet legal requirements.

\section{Corporate Governance Practices and Organizational Performance}

It is a generally accepted view that good corporate governance enhances a firms performance (Nyaga, 2007, 2000, PGCT,1999). Indeed good governance provides a firm basis for setting performance measures and an enabling environment to facilitate superior performance thus lowering the risk of poor performance (Machuki and Oketch, 2013). In for profit organizations, poor governance causes outside investors to withhold funds or buy shares therefore firms rely only on internal capital to finance ongoing operations and expansion. Overall economic performance consequently suffers because business opportunities would be missed and temporary financial problems at individual firms would spread quickly to stakeholders (Machuki and Oketch, 2013). Mallon (2010) points out that a good organization will have corporate governance structures that set clear mission and goals as well as implementation and monitoring system to guide performance.

Empirical evidence on the relationship between board size and performance is mixed. According to the resource dependency theory, the board of directors, with their high level of links with the external environment is expected to play an important role. Hence, bigger board having representation of people with diverse backgrounds is expected to bring diversified knowledge and expertise to the board. According to Van den Berghe and Levrau (2004), increasing the number of directors increases the pool of expertise available to 
the firm hence larger boards are likely to have more knowledge and skills at their disposal as compared to smaller boards. Forbes and Milliken (1999) and Goodstein et al (1994) provide evidence that larger boards reduce the domination by the CEO.

According to the agency theory perspective, greater proportion of outside directors on boards help in monitoring the conflict of interests between shareholders and managers (Agrawal and Knoeber, 2012; Daily et al 1999; Duchin et al, 2010; Fama and Jensen,1983; Shleifer and Vishny, 1997). The evidence of the impact of board composition on firm performance is however inconclusive. Companies with more outside directors better and there is evidence suggesting that presence of outside directors reduce consumption of perquisite (Agrawal and Knoeber, 2012 ). Studies by Agrawal and Knoeber (1996) and Coles et al (2001) found negative impact of greater representation of outside directors on firms performance while Reddy et al (2010) found no significance effect of outside directors of firm performance.

Corporate governance envisages good strategic planning process and organizational performance measures (John and Senbet, 1998). Strategic planning management gives rise to strategic options which are useful in building sustainability and competitiveness in the environment. Indeed, good corporate governance is likely to strengthen private investment including firm performance and growth. Over the last decade, the Asian financial crisis, Enron, WorldCom, Tyco, Adelphia, Arthur Anderson, Lehman Brothers, Freddy Mac and Fanny Mae in the USA have come to represent the classic faces of failure attributable to corporate governance shortcomings (Mallin, 2010).

Good corporate governance by boards is recognized to have an effect on the quality of financial reporting, which in turn has an impact on investor confidence ((John and Senbet, 1998; Kemei, 2010). Although there is a growing body of cross-sectional evidence linking good governance to organizational performance, it remains an open question as to whether firms with good performance adopt good corporate governance practices or whether the adoption of good governance automatically leads to improved performance (Kemei, 2010) .

\section{Methodology}

The study used a cross sectional descriptive survey design. A study design is descriptive when it is concerned with why and how a variable produces change in another, and cross sectional if it involves obtaining of data from a cross section of members of a population at one point in time (Cooper and Schindler, 2003). A census of all the sugar manufacturing companies operating in Kenya was undertaken. The companies had installed cane 
crushing capacity of 29,976 tonnes of cane per day. As at June $30^{\text {th }} 2013$, there were 11 such companies

The data collected were both primary and secondary. The primary data were obtained by way of a mixture of self administered mailed and "drop and pick later" semi-structured questionnaire. The questionnaire was administered to either the Managing Director (CEO), the Company Secretary, Legal officer or Chief Auditor/Chief Finance Officer of the sugar companies.

Using both descriptive and inferential statistics, analysis existing corporate governance structures in sugar companies and their influence on performance was done and determined respectively. The study hypothesis was tested through multiple regression analysis at 95\% confidence level $(p=0.05)$. By undertaking this analysis, the nature of the independent effect (positive or negative) of each governance structure on the various indicators of corporate performance was determined. Multiple regression analysis tested the combined effect of the corporate governance on each measure of organizational performance.

Since the study conceptualized performance as the dependent variable while corporate governance practices as the independent variable, the regression model used was:

$$
\begin{aligned}
& \mathbf{y}_{1}=\mathbf{b}_{0}+\mathbf{b}_{1} \mathbf{X}_{1}+\mathbf{b}_{2} \mathbf{X}_{2}+\ldots \ldots \ldots . . . \mathbf{b}_{6} \mathbf{X}_{6}+\mathbf{e}_{\mathbf{i}} \\
& \text { Where: } \mathrm{e}_{\mathrm{i}} \quad=\quad \text { error term } \\
& \text { bo } \quad=\text { Constant variable } \\
& \mathbf{b}_{1}, \mathbf{b}_{2} \ldots \mathbf{b}_{6}=\text { the coefficients of the independent variable } \\
& \mathbf{y}_{\mathbf{1}}=\text { represent the performance (dependent variable) } \\
& \mathbf{X}_{1}, \mathbf{X}_{2}, \ldots . \mathbf{X}_{6}=\text { corporate governance practices represented by } \\
& \text { (CG1...CG6) }
\end{aligned}
$$

\section{Findings}

The objectives of this study were to establish corporate governance practice by sugar companies and to determine the influence of the corporate governance practice on the organizational performance of the companies. The study sought information on the existence of subcommittees of the board, number of such subcommittees, frequency of board meetings, convening of board meetings, duration of the meetings, and mode of making board decisions. Further, five key functions of corporate governance (board establishment and functions, board meetings, managing director, board structure, regulatory framework) were presented to the respondents who were required to rate the extent to which the sugar companies practiced them. The results are presented in Tables 1 to 11 . 
Table 1: Existence of subcommittees within the board

\begin{tabular}{|c|c|c|}
\hline Response & Frequency & Percent \\
\hline Yes & 11 & 100 \\
\hline No & 0 & 0 \\
\hline Total & 11 & 100 \\
\hline
\end{tabular}

The existence of subcommittees of the board was used to determine the structure of the boards of the sugar companies. The existence of subcommittees is a pointer to division of responsibilities which is a key corporate governance requirement. The results in Table 1 show that existence of subcommittees in all the companies. All the firms therefore had adopted this corporate governance practice.

Table 2: Number of board subcommittees

\begin{tabular}{|c|c|c|}
\hline Number & Frequency & Percent \\
\hline $1-2$ & 5 & 45.5 \\
\hline $3-4$ & 5 & 45.5 \\
\hline Above 5 & 1 & 9.0 \\
\hline Total & 11 & 100 \\
\hline
\end{tabular}

As earlier stated, having subcommittees is good management practice as it takes advantage of professional diversity. However, too many subcommittees may not be good for an organization as it may result in duplication of duties hence resulting in inefficiency in operations. Results in Table 2 show that $91 \%$ of the companies had between 1 and 4 board subcommittees.

The study sought to know the frequency of meetings held by the sugar companies. This is very critical information since boards transact their mandate in meetings and hence board meetings are core in best code of practice of corporate governance. The results in Table 3 show that $90.9 \%$ of the companies held 6 and above board meetings in the year 2011/2012.

Table 3: Frequency of board meetings in the year 2011/2012

\begin{tabular}{|c|c|c|}
\hline Number & Frequency & Percent \\
\hline $1-5$ & 1 & 9.1 \\
\hline $6-12$ & 6 & 54.5 \\
\hline Above 12 & 4 & 36.4 \\
\hline Total & 11 & 100 \\
\hline
\end{tabular}

Indeed too many meetings could mean that the board is micromanaging the company and hence not giving the CEO time to manage the company while too few board meetings implies that the CEO has too much freedom which can be detrimental to the principals and other stakeholders. Majority of the meetings (54.5\%) are convened by the board chairman (Table 4). 
Table 4: Convener of the Board Meetings

\begin{tabular}{|c|c|c|}
\hline & Frequency & Percent \\
\hline Secretary & 5 & 45.5 \\
\hline Chairman & 6 & 54.5 \\
\hline Total & 11 & 100 \\
\hline
\end{tabular}

The results show that the meetings were either convened by the chairman or the secretary. The average duration of the meetings is 3 to 5 hours at $81.8 \%$ as shown in Table 5.

Table 5: Average Duration of Board Meetings

\begin{tabular}{|c|c|c|}
\hline Duration & Frequency & Percent \\
\hline Below 2 hours & 2 & 18.2 \\
\hline 3-5 hours & 9 & 81.8 \\
\hline Total & 11 & 100 \\
\hline
\end{tabular}

These results point to the fact that majority of the boards utilized their time well as board meetings should normally take 2 to 3 hours for quality outcomes to be realized. Indeed long meetings indicate poor time management and planning in the form of agenda items. The mode of making decisions is $100 \%$ consensus (Table 6).

Table 6: Mode of Making Board Decisions

\begin{tabular}{|c|c|c|}
\hline Mode & Frequency & Percent \\
\hline Consensus & 11 & 100 \\
\hline Voting & 0 & 0 \\
\hline Total & 11 & 100 \\
\hline
\end{tabular}

The results point to the fact that issues are normally debated at length which is an important aspect of corporate governance. The corporate governance practice of board establishment and functions was captured using 16 descriptive statements and the results are presented in Table 7.

Table 7: Board Establishment and Functions

\begin{tabular}{|c|c|c|c|}
\hline Descriptive statement & $\mathbf{N}$ & Mean & Std Dev. \\
\hline The board size and composition are right for the organization & 11 & 3.64 & 0.67 \\
\hline Every Board member has been supplied with a letter of appointment & 11 & 5.0 & 0.00 \\
\hline $\begin{array}{c}\text { The letter of appointment clearly defines the roles and functions of the } \\
\text { Board and the specific role of each director }\end{array}$ & 11 & 4.36 & 0.50 \\
\hline The Board understands, agrees, defines and propagates its functions \\
on an annual basis & 11 & 4.82 & 0.40 \\
\hline $\begin{array}{c}\text { The Board knows and understands the Company's beliefs, values, } \\
\text { philosophy, mission, and vision and reflects understanding on key } \\
\text { issues throughout the year }\end{array}$ & 11 & 4.18 & 0.87 \\
\hline $\begin{array}{c}\text { The Board leads development of vision, mission, policies and plans } \\
\text { (The Board devotes significant time and serious thought to the } \\
\text { organizations long term objectives and to the strategic options } \\
\text { available to achieve them) }\end{array}$ & 11 & 4.27 & 0.90 \\
\hline $\begin{array}{c}\text { The Board has defined and communicated to management the scope } \\
\text { and powers, roles and responsibilities to be adhered to by management } \\
\text { (The Board delegates sufficient authority to management to lead } \\
\text { organization) }\end{array}$ & 11 & 4.00 & 1.09 \\
\hline
\end{tabular}




\begin{tabular}{|c|c|c|c|}
\hline $\begin{array}{c}\text { The majority of the Board time is not spent on issues of day-to-day } \\
\text { management }\end{array}$ & 11 & 3.0 & 0.89 \\
\hline $\begin{array}{c}\text { The Board ensures that the organization has sufficient and appropriate } \\
\text { resources to achieve its strategic goals }\end{array}$ & 11 & 4.00 & 1.09 \\
\hline $\begin{array}{c}\text { Proposals from management are analyzed and debated vigorously } \\
\text { before being approved by the Board. A proposal that is considered } \\
\text { inappropriate is declined }\end{array}$ & 11 & 4.00 & 0.77 \\
\hline Term limit of Board membership is adhered to & 11 & 3.73 & 1.10 \\
\hline $\begin{array}{c}\text { Board committees exist to advice on specific functional areas } \\
\text { A broad range of appropriate performance indicators are used to } \\
\text { monitor the performance of management.( Reliability is not placed } \\
\text { solely on the financial statements provided by management) }\end{array}$ & 11 & 4.64 & 0.67 \\
\hline The Board regularly reviews company performance & 11 & 4.09 & 0.54 \\
\hline Board decisions are influenced by founder members & 11 & 2.91 & 1.14 \\
\hline Board members engage in financial transactions with the company & 11 & 1.82 & 1.25 \\
\hline
\end{tabular}

Findings indicate that letters of appointment; definition and propagation of board functions on an annual basis; existence of board sub committees; and reviews of company performance by boards were highly rated indicating that the majority of sugar company boards have letters of appointment for members, define and propagate board functions annually; have board subcommittees, and regularly review company performance.

The results show that engagement by board members in financial transactions with the company is rare. To capture the corporate governance practice of board meetings, 6 descriptive statements were used and the results are presented in Table 8 . The results show a high rating of the majority of all the descriptive statements (mean scores between 3.91 and 5.00 with standard deviations of between 0.00 and 0.94 ).

Table 8: Board Meetings

\begin{tabular}{|l|c|c|c|}
\hline Descriptive statement & N & Mean & $\begin{array}{c}\text { Std } \\
\text { deviation }\end{array}$ \\
\hline $\begin{array}{l}\text { Every Board member has been supplied with a Board } \\
\text { manual and a copy of standing orders and regulations } \\
\text { governing conduct of Board meetings }\end{array}$ & 11 & 3.91 & 0.94 \\
\hline $\begin{array}{l}\text { Every Board member is supplied with a calendar of } \\
\text { meetings showing dates of meetings, and committee } \\
\text { meetings }\end{array}$ & 11 & 4.27 & 0.90 \\
\hline $\begin{array}{l}\text { Board members receive timely and accurate minutes, } \\
\text { advance written agendas and meeting notices, and clear and } \\
\text { concise background material to prepare in advance of } \\
\text { meetings }\end{array}$ & 11 & 4.73 & 0.47 \\
\hline $\begin{array}{l}\text { Absenteeism from Board meetings is the exception rather } \\
\text { than the rule }\end{array}$ & 11 & 4.73 & 0.46 \\
\hline $\begin{array}{l}\text { Board members are facilitated but not overtly influenced by } \\
\text { the chairperson }\end{array}$ & 11 & 4.64 & 0.50 \\
\hline $\begin{array}{l}\text { All proceedings and resolutions of the Board are recorded } \\
\text { accurately, adequately and on a timely basis }\end{array}$ & 11 & 5.00 & 0.00 \\
\hline
\end{tabular}


These results reveal the high quality of board meetings since majority of members have board manuals, calendar of meetings, have agendas and minutes distributed in time and absenteeism is not the norm. The corporate governance practice of Managing Director (CEO) of the company was captured using 6 descriptive and the results are presented in Table 9.

Table 9: Managing Director (CEO) of the Company

\begin{tabular}{|l|c|c|c|}
\hline Descriptive statement & N & Mean & $\begin{array}{c}\text { Standard } \\
\text { deviation }\end{array}$ \\
\hline The CEO has a detailed job description & 11 & 4.55 & 0.52 \\
\hline $\begin{array}{l}\text { The CEO handles queries from stakeholders } \\
\text { accurately and in a timely manner }\end{array}$ & 11 & 4.36 & 0.81 \\
\hline Recruitment for all positions are open and fairly done & 11 & 3.45 & 1.44 \\
\hline $\begin{array}{l}\text { The CEO undergoes a formal performance evaluation } \\
\text { at least annually }\end{array}$ & 11 & 3.36 & 1.43 \\
\hline $\begin{array}{l}\text { The board supports the CEO in the implementation of } \\
\text { policies and procedures }\end{array}$ & 11 & 4.91 & 0.30 \\
\hline $\begin{array}{l}\text { There is a formal structure for conflict management } \\
\text { and the CEO has a cordial relationship with the board }\end{array}$ & 11 & 4.36 & 0.81 \\
\hline
\end{tabular}

The results show a high rating for the board support to the CEO in the implementation of policies and procedures (mean score 4.91; standard deviation 0.30). The board structure was captured using 5 descriptive statements and the results are presented in Table 10.

The results indicate that the board has a balanced mix of executive, non-executive and independent non executive directors (mean score 3.55; standard deviation 1.29) and the roles of the chairperson of the board and CEO are separated and held by different persons (mean score 3.55; standard deviation 1.51).

Table 10: Board Structure

\begin{tabular}{|l|c|c|c|}
\hline Descriptive statement & N & Mean & Std deviation \\
\hline $\begin{array}{l}\text { The Board has a balanced mix of Executive, Non- } \\
\text { executive, and Independent Non-Executive Directors }\end{array}$ & 11 & 3.55 & 1.29 \\
\hline $\begin{array}{l}\text { The role of Chairperson of the Board and Chief } \\
\text { Executive Officer are separated and held by different } \\
\text { persons }\end{array}$ & 11 & 3.55 & 1.51 \\
\hline $\begin{array}{l}\text { The Board has established and appointed committees } \\
\text { with defined terms of reference, composition, and } \\
\text { reporting requirements. }\end{array}$ & 11 & 3.45 & 1.13 \\
\hline $\begin{array}{l}\text { The Board has established and appointed an Executive } \\
\text { Committee, an Audit Committee, and a Board } \\
\text { Appointment and Remuneration Committee }\end{array}$ & 11 & 2.45 & 0.69 \\
\hline $\begin{array}{l}\text { The terms of reference of each of committee are } \\
\text { restricted and defined }\end{array}$ & 11 & 2.82 & 0.75 \\
\hline
\end{tabular}


The respondents were further presented with three statements which are descriptive of the aspects of regulatory and legal requirements for sugar companies. Table 11 presents the results on these aspects.

Table 11: Regulatory Framework

\begin{tabular}{|c|c|c|c|}
\hline Descriptive statement & $\mathbf{N}$ & Mean & Std deviation \\
\hline $\begin{array}{c}\text { The Board has procedures in place to ensure that the } \\
\text { organization is meeting its legal responsibilities }\end{array}$ & 11 & 4.64 & 0.50 \\
\hline $\begin{array}{c}\text { The relevant authority is informed of important } \\
\text { changes such as name, bank accounts, bank } \\
\text { signatories, postal and physical addresses, board } \\
\text { membership }\end{array}$ & 11 & 4.73 & 0.47 \\
\hline $\begin{array}{c}\text { The company files annual returns to the relevant } \\
\text { authority(ies) including audit report if necessary }\end{array}$ & 11 & 5.00 & 0.00 \\
\hline
\end{tabular}

The findings show that all the three descriptive indicators were rated highly (mean score ranging from 4.64 to 5.0; standard deviation 0.0 to 0.5 ). The results reveal a high regard of the laws and regulations governing the sugar companies in Kenya.

\section{Corporate Governance Practice and Performance}

In order to determine the influence of the corporate governance practices on the organizational performance of the sugar producing companies, this study adopted the modified balanced scorecard model to gauge key performance variables. Five balanced score card performance indicators (financial perspective; customer focus; internal business processes perspective measures; innovation, learning and growth; and quality perspective) were used. Through multivariate regression analysis at different stages, the results were obtained at $95 \%$ confidence levels and presented. The nature of the independent effect (positive or negative) was also determined. The independent effect of corporate governance practices on financial performance is reported in Table 12.

Table 12: Independent Effect of CG Practices on Financial Performance Perspective

\begin{tabular}{|l|l|l|l|l|l|}
\hline \multirow{2}{*}{} & \multicolumn{2}{|l|}{$\begin{array}{l}\text { Unstandardized } \\
\text { coefficients }\end{array}$} & $\begin{array}{l}\text { Standardized } \\
\text { coefficients }\end{array}$ & t value & \multirow{2}{*}{ Sig. } \\
\cline { 2 - 5 } & $\mathrm{B}$ & Std error & Beta $(\beta)$ & & \\
\hline (Constant) & 1.712 & 1.214 & & 1.410 & 0.218 \\
\hline $\begin{array}{l}\text { Board Establishment and } \\
\text { Functions }\end{array}$ & 1.776 & 0.330 & 1.544 & 5.389 & 0.003 \\
\hline Board meetings & 0.490 & 0.232 & 0.607 & 2.115 & 0.088 \\
\hline $\begin{array}{l}\text { Managing Director (CEO) of } \\
\text { the company }\end{array}$ & -0.943 & 0.228 & -1.333 & -4.137 & 0.090 \\
\hline Board Structure & 0.601 & 0.117 & 1.502 & 5.156 & 0.040 \\
\hline Regulatory Framework & -0.997 & 0.225 & -0.743 & -4.430 & 0.007 \\
\hline Performance: Financial perspective measures
\end{tabular}


The results in Table 14 show positive effect for board establishment and function, board meetings, and board structure. High impact is reported for board establishment and functions $(\beta=1.54)$ and board structure $(\beta=1.50)$. The study reports statistically significant results for the independent effect of Managing director (CEO) with the regulatory framework having a negative effect ( $p>0.05$ ). Normally we would expect that the leadership qualities of the Managing director would have a significant effect on financial performance of the organization.

The independent effect of CG practices on customer and people perspective is reported in Table 13 .

Table 13: Independent Effect of CG Practices on Customer Perspective

\begin{tabular}{|l|l|l|l|l|l|}
\hline & \multicolumn{2}{|l|}{$\begin{array}{l}\text { Unstandardized } \\
\text { coefficients }\end{array}$} & $\begin{array}{l}\text { Standardized } \\
\text { coefficients }\end{array}$ & t value & sig \\
\cline { 2 - 6 } & B & $\begin{array}{l}\text { Std } \\
\text { error }\end{array}$ & Beta $(\beta)$ & & \\
\hline (Constant) Establishment and & -0.047 & 3.943 & & -0.012 & 0.991 \\
\hline $\begin{array}{l}\text { Board } \\
\text { Functions }\end{array}$ & 1.134 & 1.071 & 0.698 & 1.060 & 0.338 \\
\hline Board meetings & 0.576 & 0.752 & 0.505 & 0.766 & 0.478 \\
\hline $\begin{array}{l}\text { Managing Director (CEO) of the } \\
\text { company }\end{array}$ & -0.486 & 0.740 & -0.486 & -0.657 & 0.540 \\
\hline Board Structure & 0.521 & 0.379 & 0.920 & 1.374 & 0.228 \\
\hline Regulatory Framework & -0.711 & 0.731 & -0.376 & -0.973 & 0.375 \\
\hline Performance=Customer Perspective & \multicolumn{5}{l}{} \\
\hline
\end{tabular}

The study reports positive effect for the CG practices of board establishment and functions, board meetings, and board structure. The Managing director (CEO) and regulatory framework have a negative effect ( $\mathrm{p}$ $>0.05$ ). Further, the CG practice of board structure had a relatively high positive effect $(\beta=0.92)$ (Table 4.15). Issues that are covered under customers and people are normally external and this can explain the positive correlation with board functions.

The independent effects of CG practices on internal business processes perspective are reported in Table 14.

Table 14: $\quad$ Independent Effect of CG Practices on Internal Business Processes

Perspective

\begin{tabular}{|l|l|l|l|l|l|}
\hline & \multicolumn{2}{|l|}{$\begin{array}{l}\text { Unstandardized } \\
\text { coefficients }\end{array}$} & $\begin{array}{l}\text { Standardized } \\
\text { coefficients }\end{array}$ & t value & Sig. \\
\cline { 2 - 6 } & $\mathrm{B}$ & Std error & Beta $(\beta)$ & & \\
\hline (Constant) & 0.245 & 1.770 & & 0.138 & 0.895 \\
\hline $\begin{array}{l}\text { Board Establishment and } \\
\text { Functions }\end{array}$ & 1.693 & 0.481 & 1.231 & 3.522 & 0.017 \\
\hline Board meetings & -2.227 & 0.338 & -0.235 & -0.673 & 0.531 \\
\hline $\begin{array}{l}\text { Managing Director (CEO) of the } \\
\text { company }\end{array}$ & -0.286 & 0.332 & -0.338 & -0.860 & 0.429 \\
\hline Board Structure & 0.815 & 0.170 & 1.702 & 4.789 & 0.005 \\
\hline Regulatory Framework & -0.716 & 0.328 & -0.447 & -2.183 & 0.081 \\
\hline Performance= Internal Business Processes Perspective \\
\hline
\end{tabular}


As shown in Table 16, the study reports a strong correlation between the independent $\mathrm{CG}$ practices of board establishment and functions $(\beta=1.23)$ and board structure $(\beta=1.72)$. In organizations, the setting of vision, mission, and objectives is key to success. More important is that the board should be conversant and identify with the strategic objectives. Other board functions like regular evaluation of the performance of the company and the CEO are equally important in performance enhancement.

The independent effect of CG practices on innovation, learning and growth perspective is reported in Table 15.

Table 15: Independent Effect of CG Practices on Innovation, Learning and Growth Perspective.

\begin{tabular}{|c|c|c|c|c|c|}
\hline & \multicolumn{2}{|c|}{$\begin{array}{l}\text { Unstandardized } \\
\text { coefficients }\end{array}$} & \multirow{2}{*}{$\begin{array}{l}\text { Standardized } \\
\text { coefficients } \\
\text { Beta }(\beta)\end{array}$} & \multirow[t]{2}{*}{ t value } & \multirow[t]{2}{*}{ Sig. } \\
\hline & $\mathrm{B}$ & Std error & & & \\
\hline (Constant) & 1.1 .728 & 1.971 & & 0.877 & 0.421 \\
\hline $\begin{array}{c}\text { Board Establishment and } \\
\text { Functions }\end{array}$ & 0.232 & 0.535 & 0.112 & 0.433 & 0.683 \\
\hline Board meetings & 0.604 & 0.376 & 0.415 & 1.607 & 0.169 \\
\hline $\begin{array}{c}\text { Managing Director (CEO) } \\
\text { of the company }\end{array}$ & 0.272 & 0.370 & 0.213 & 0.734 & 0.496 \\
\hline Board Structure & 0.400 & 0.189 & 0.554 & 2.112 & 0.088 \\
\hline Regulatory Framework & -0.137 & 0.365 & -0.057 & -0.374 & 0.724 \\
\hline
\end{tabular}

The study reports statistically significant results for the independent positive effects of the CG structures of board establishment and functions, board meetings, Managing director (CEO) and board structure ( $p>0.05$ ). Negative impact is reported for regulatory framework (Table 4.17). Normally, innovation, learning and growth is expected to be correlated to board functions and company management structure.

The independent effect of CG practices on quality perspective is given in Table 16

Table 16: Independent Effect of CG Practices on Quality Perspective

\begin{tabular}{|c|c|c|c|c|c|}
\hline & \multicolumn{2}{|c|}{$\begin{array}{l}\text { Unstandardized } \\
\text { coefficients }\end{array}$} & \multirow{2}{*}{$\begin{array}{l}\text { Standardized } \\
\text { coefficients } \\
\text { Beta }(\beta)\end{array}$} & \multirow[t]{2}{*}{ t value } & \multirow[t]{2}{*}{ Sig. } \\
\hline & $\mathrm{B}$ & Std error & & & \\
\hline (Constant) & -3.531 & 2.093 & & -1.688 & 0.152 \\
\hline $\begin{array}{l}\text { Board Establishment } \\
\text { and Functions }\end{array}$ & 1.410 & 0.568 & 0.533 & 2.481 & 0.056 \\
\hline Board meetings & 0.005 & 0.399 & 0.003 & 0.013 & 0.990 \\
\hline $\begin{array}{l}\text { Managing Director } \\
(\mathrm{CEO}) \text { of company }\end{array}$ & 0.671 & 0.393 & 0.428 & 1.709 & 0.148 \\
\hline Board Structure & 0.646 & 0.201 & 0.728 & 3.214 & 0.024 \\
\hline Regulatory Framework & -0.745 & 0.388 & -0.251 & -1.920 & 0.113 \\
\hline
\end{tabular}


The study reports statistically significant results for the independent effect of the CG practices of board functions, board meetings, managing director $(\mathrm{CEO})$, and board structure $(\mathrm{p}>0.05)$. Relatively high positive impact is reported for board structure $(\beta=0.72)$.

In conclusion, from all the above results, the study has reported mixed results with regard to statistical significance of the independent effects of corporate governance practices on the various measures of performance. The results of the combined effects were generated by taking the outputs of the regression analysis with $\mathrm{R}$ values, $\mathrm{R}^{2}$, F-ratio and significant levels for the models (multiple linear regression analysis gives the multiple $R, R^{2}$, and $F$ ratio as well as significance level values). Multiple $\mathrm{R}$ value shows the strength of the relationship between the independent variables i.e. corporate governance (combined) and each measure of performance (dependant variables). The $\mathrm{R}^{2}$ value shows the amount of the performance indicator that is explained by the combined effect of the corporate governance structures. The F-ratio shows the overall statistical significance of the model at $95 \%$ confidence level $(p=0.05)$. The results are shown in Table 17.

Table 17: Combined Corporate Governance Practices and Performance.

\begin{tabular}{|l|l|l|l|l|l|}
\hline Model & $\mathrm{N}$ & $\begin{array}{l}\text { Multiple } \\
\mathrm{R}\end{array}$ & $\mathrm{R}^{2}$ & $\mathrm{~F}$ & $\mathrm{Sig}$ \\
\hline Financial performance measures & 11 & 0.350 & 0.123 & 1.258 & 0.291 \\
\hline Customers perspective measures & 11 & 0.636 & 0.404 & 6.102 & 0.036 \\
\hline $\begin{array}{l}\text { Internal business processes } \\
\text { perspective measures }\end{array}$ & 11 & 0.683 & 0.467 & 7.883 & 0.020 \\
\hline $\begin{array}{l}\text { Innovation, learning and growth } \\
\text { perspective measures }\end{array}$ & 11 & 0.936 & 0.877 & 4.160 & 0.013 \\
\hline Quality perspective measures & 11 & 0.907 & 0.823 & 4.957 & 0.011 \\
\hline Corporate
\end{tabular}

Corporate governance structures: Board establishment and functions, Board meetings, Managing director (CEO) of the company, Board structure, Regulatory framework,

The combined effect of corporate governance practices on the various performance measures is given in Table 17. The results show that there is a correlation between corporate governance practice and the various measures of performance. Corporate governance has a weak relationship to financial performance $(\mathrm{R}=0.35)$ with only $12.3 \%$ of financial performance explained by the corporate governance practice. This influence is not statistically significant $(\mathrm{F}=1.258, \mathrm{p}>0.05)$.

There is a strong correlation between corporate governance practices and customer and people perspective $(\mathrm{R}=0.63)$ with the $40 \%$ of the performance explained by the corporate governance practices. This influence is quite high as observed by the value of the $\mathrm{F}$ statistic $(\mathrm{F}=6.10, \mathrm{R}=0.63, \mathrm{p}$ > 0.05 ) and is statistically significant.

There is also a strong relationship between corporate governance practices and internal business processes $(\mathrm{R}=0.68)$ where $46 \%$ of internal 
process performance is attributed to corporate governance practices $\left(\mathrm{R}^{2}=0.467\right)$. This is statistically significant $(\mathrm{F}=7.88, \mathrm{p}<0.05)$. Innovation, learning, and growth performance as a function of corporate governance practice has a strong relationship $(\mathrm{R}=0.936)$ where $87 \%$ of the performance is attributed to corporate governance practices $(\mathrm{R} 2=0.877)$. The influence is statistically significant $(\mathrm{F}=4.16, \mathrm{p}<0.05)$. Finally, the results indicate that corporate governance practices have a strong effect on quality performance $(\mathrm{R}=0.907)$ with $82 \%$ of the performance explained by corporate governance. The influence is strong as observed by the high value of the $F$ statistic $(F=4.95$, $\mathrm{p}>0.05)$ which is statistically significant.

\section{Discussion}

The study sought to establish the corporate governance practices in the sugar producing companies in Kenya and to determine the effect of the corporate governance practices on the performance of the sugar companies. The study was guided by relevant theories as well as empirical studies in the areas of corporate governance and organizational performance. The findings of this study have provided evidence that all the sugar producing companies in Kenya have boards of directors in place. Most of the boards have 3 to 4 subcommittees which meet fairly frequently. Corporate governance practices revolve around composition of boards, frequency of board meetings, independence of board of directors, independence of internal audit and audit committee, and CEO-Chair duality. One important function of the board of directors is the monitoring of the performance of top management as postulated in the agency theory.

Results of this study have also established that board members in the studied sugar companies are normally supplied with appointment letters which detail out their responsibilities. Results further show that the boards normally undertake a review of the performance of the company as well as the review of CEOs performance on an annual basis. The board of directors is an important institution in the governance of corporations. The board is viewed as the apex of internal decision control system of organizations (Fama and Jensen, 1983).

Findings of this study further indicate that the role of chairperson of the board and CEO are separated and held by different persons in over $50 \%$ of the sugar companies in Kenya. The two roles were found to be completely separated in the government and publicly owned sugar companies while they are combined in the family owned firms. Good corporate governance practice demands a separation of roles between the board and management in order to enhance appropriate oversight and supervision as stipulated in the agency theory. There are opposing viewpoints as to the effectiveness of the board when the position of the chairperson of the board and that of the CEO of the 
firm are held by the same person, a situation often referred to as 'combined leadership'.

Board activity refers to the frequency of meetings held by the board and is an aspect of the resource dependency theory linking corporate governance and performance. The findings of this study indicate that majority of the sugar companies hold an average of 6 to 12 board meetings in a year with meetings generally lasting 3 to 5 hours and board decisions are arrived at through consensus. Conger et al (1998) suggest that board-meeting time is an important resource in improving the effectiveness of a board with directors who meet more frequently being more likely to perform their duties in accordance with the shareholders' interests. Jensen (1993) however opined that frequent board meetings serve as a fire-fighting device rather than as a proactive measure for giving direction on policy and that higher board activity is likely to symbolize a response to poor performance.

The findings of this study also show that the corporate governance practices affected performance of the sugar companies although the degree of impact differed. Board establishment and functions and board structure were found to wield the strongest positive effect while the financial performance perspectives showed the weakest correlation to the corporate governance structures. The results support the findings from other studies on corporate governance. Several empirical studies in Kenya on corporate governance and financial performance of firms (Awino, 2009; Abwoga, 2001; Gicheru,2007; Kemei, 2010; Kiamba 2008; Kitetei, 2009; Maina 2009; Ombayo, 1999; Onzare, 2008; Murage, 2008; Njoka, 2008) have established that there is a relationship between firm performance and frequency of board meetings, board size, the ratio of outside directors to total directors, and the percentage of insider share ownership. A study by Gathura (2007) seeking to determine the relationship between various components of corporate governance and financial performance of manufacturing firms listed in the NSE revealed a linear relationship between performance, frequency of board meetings, CEO compensation and board compensation. Machuki and Oketch (2013) examined the relationship between corporate governance structures and performance of HIV/AIDS Non-Governmental organizations and concluded that corporate governance is important and responsible for a large proportion of the good performance achieved. Duke and Kanpang's (2011) findings also get support in the current study.

Results of this study have demonstrated that corporate governance practices influence the performance of the organizations under study. These findings therefore offers some support to the various corporate governance theories such as stakeholder theory (Freeman,1984), resource dependence theory (Aldrich and Pfeffer 1976), agency theory (Jensen and Meckling 1976), 
and stewardship theory (Donaldson and Davis 1994) which all propose that adopting good corporate governance results in positive performance.

The findings have revealed that corporate governance is responsible for the performance achieved by the companies. The results further reveal that individual corporate governance structures acting on their own do not lead to improvement in performance. Consequently, it is therefore recommended that the sugar firms should work towards implementing and maintaining good governance structures in order to improve their operational performance. To policy makers, particularly the Kenya Sugar Board and the government ministry, the study recommends that they insist that all the sugar firms institute corporate governance practices in the firms and should be part of the performance contracts. Ultimately, academicians and researchers, policy makers and management practitioners would find the study's findings impactful.

\section{Limitations and Suggestions for Further Research}

Quite a number of challenges were encountered during this study. The topic of study required responses from a pre-selected cadre of respondents due to the level of accuracy and authenticity required. Only those who sit in the management boards were selected to answer the questionnaire (either the CEO, secretary to the board/legal officer, chairman of the board, auditor, and Finance officer). Since the unit of study was the sugar company and with the limited number of sugar producing companies (11), the total number of filled questionnaires could only be 11 (100\% return) which were rather few for the appropriate statistical power. .Although the responses were indexed before analysis, it is believed that a larger sample could have enhanced the data pool and influenced the outcome.

Several CEOs, by nature of their heavy schedules, did not have time for a face to face interview and opted for the questionnaire to be mailed to them. The researcher could therefore not interrogate some of the responses. In addition, respondents generally had emotional attachment to their organizations and the researcher could therefore not rule out personal bias in the responses.

The study focused on the sugar industry which has its own unique characteristics. It would be important to carry out a similar study in a related industry in order to compare the results.

Further, the study was a census survey which generally looked at all the sugar companies in Kenya. It is anticipated that the results would be different if the study concentrated on looking at corporate governance practices in one particular sugar company.

The study was a census survey which looked at all the sugar companies in Kenya. Since the results point to the existence of corporate governance 
practices in all the companies studied, it is suggested that further work be done on corporate governance practices in a specific sugar company with the detailed study looking at all the operational divisions of the particular sugar companies.

\section{References:}

1. Abwoga, D. (2001). Corporate Governance Practices in Publicly Quoted Family Companies in Kenya. (Unpublished MBA Project), School of Business, University of Nairobi, Kenya.

2. Aldrich, H.E., \& Pfeffer, J. (1976). Environments of Organizations. Annual Review of Sociology, 2, 79-105.

3. Agrawal, A. \& Knoeber,C.R. (2012), Corporate Governance and Firm Performance. In Thomas,C.R. \& Shughart II, W.F.(Eds.), Oxford Handbook in Managerial Economics (pp 111-134). Oxford University Press, New York, NY.

4. Agrawal, A. \& Knoeber,C.R. (1996). Firm Performance and Mechanisms to Control Agency Problems between Managers and Shareholders. Journal of Financial and Quantitative Analysis, 31, 377397.

5. Awino ,A.M. (2009). A Survey of Corporate Governance Practices by Savings and Credit Co-operative Societies in Kakamega Municipality. (Unpublished MBA Project), School of Business, University of Nairobi, Kenya.

6. Coles, J.L., Michael, L.L., and Meshke, J. F. (2012), Structural Models and Endogeneity in Corporate Finance: The Link between Managerial Ownership and Corporate Performance. Journal of Financial Economics , 103,149-169.

7. Conger,J.A., Finrgold, D.,and Lawler III, E. (1998). Appraising Boardroom Performance, Harvard Business Review, 76 (1), 136-148.

8. Conner, R.K. and Prahalad, C.K. (1996). A Resource Based Theory of the Firm: Knowledge versus Opportunism. Organization Science, 7 (5), 477-501.

9. Cooper, D.R., \& Schindler, P.S. (2003). Business Research Methods. ( $7^{\text {th }}$ ed.), New York, NY, McGraw Hill.

10. Daily, C.M., Certo, S.T., and Dalton, D.R. (1999). A Decade of Corporate Women; Some Progress in the Boardroom, None in the Executive Suite. Strategic Management Journal, 20, 93-99.

11. Decoene, V. \& Bruggenman, W. (2006). Strategic Alignment and Middle-Level Managers' Motivation in a Balanced Score Card Setting. International Journal of Operations \& Production Management, 26 (4), 429-448. 
12. Dezoort, F.T., Hermanson, D.R., Archambeault, D.S. and Reed, S.A.(2002). Audit Committee Effectiveness: A Synthesis of the Empirical Audit Committee Literature, Journal of Accounting Literature, 21, 38-75.

13. Donaldson, L. \& Davis, J.H. (1994). Boards and Company Performance: Research Challenges the Conventional Wisdom, Corporate Governance: An International Review. 2(3), 151-160.

14. Duchin, R, Matsusaka, J.G. and Ozbas,O. (2010). When are Outside Directors Effective?, Journal of Financial Economics, 96,195-214.

15. Duke, J., \& Kanpang, K. (2011). Linking Corporate Governance with Organizational Performance: New Insights and Evidence from Nigeria, Global Journal of Management and Business Research, 11(12), 47-57.

16. Faleye,O., Rani, H. and Udi, H. (2011). The Costs of Intense Board Monitoring, Journal of Financial Economics, 101, 160-181.

17. Fama, E.F. (1980). Agency Problems and the Theory of the Firm, Journal of Political Economy, 88, 288-307.

18. Fama,E.,\& Jensen,N. (1983). The Separation of Ownership and Control, Journal of Law and Economics, 26, 301-325.

19. Forbes, D., \& Milliken, F. (1999). Cognition and Corporate Governance: Understanding Board of Directors as Strategic Decision Making Groups, Academy of Management Review, 3, 489-605.

20. Freeman, R.E. (1984).Corporate Governance: A Stakeholder Approach. London, U.K. Pittman Books, Ltd.

21. Gicheru, A.K. (2007). Corporate Governance Practices and Firm Financial Performance: The Case of Pension Schemes in Kenya. (Unpublished MBA Project), School of Business, University of Nairobi, Kenya.

22. Goodstein, J., Gautam,K., and Boeker, W. (1994). The Effects of Board Size and Diversity on Strategic Change, Strategic Management Journal, 22, 1087-1111.

23. Hillman, A. \& Dalziel, T. 2003, Boards of Directors and Firm Performance: Integrating Agency and Resource Dependence Perspectives, Academy of Management Review, 28, 383-396.

24. Jensen, M.C. (1993). The Modern Industrial Revolution, Exit, and the Failure of Internal Control Systems, Journal of Finance, 48, 831-880.

25. Jensen, M \& Meckling, M. (1976). Theory of the Firm: Managerial Behavior, Agency Costs, and Ownership Structure, Journal of Financial Economics, 3, 305-360.

26. John, K. \& Senbet, L.W. (1998). Corporate Governance and Board Effectiveness. Journal of Banking and Finance, 22, 371-403.

27. Kaplan, R. S.,\& Norton, D. P. (1996). The Balanced Scorecard, Boston; Harvard Business School Press, 21. 
28. Kenya Sugar Research Foundation (KESREF), (2012), Economic Review of the Kenya Sugar Sub-Sector, 2011. Kenya Sugar Research Foundation, Kenya.

29. Kiamba, J. M. (2008). The Effect of Corporate Governance on Financial Performance of Local Authorities in Kenya. (Unpublished MBA Project), School of Business, University of Nairobi, Kenya.

30. Kemei, R.K. (2010). Corporate Governance Practices and Performance of Small Scale Tea Processing Companies in Kenya. (Unpublished MBA Project), School of Business, University of Nairobi, Kenya.

31. Kitetei, E.M. (2009). The Effect of Corporate Governance Practices on Financial Performance of Deposit Taking Micro-Finance Institutions in Kenya. (Unpublished MBA Project), School of Business, University of Nairobi, Kenya.

32. Love, I. (2011). Corporate Governance and Performance around the World: What we Know and What we Don't Know. The World Bank Research Observer, 25(1), 42-70.

33. Machuki, V. N. \& Oketch, N.A. (2013). Corporate Governance Structures and Performance of HIV/AIDS NGOS in Nairobi, Kenya. African Journal of Business and Management, 3, 163-181.

34. Maina, A.M. (2009). An Analysis of Corporate Governance Reporting in Companies Listed at the NSE. (Unpublished MBA Project), School of Business, University of Nairobi, Kenya.

35. Mallin, C. (2010). Corporate Governance ( $3^{\text {rd }}$ Ed) . Oxford, U.K: Oxford University Press.

36. Miller, D. (2003). Resource Based View. Strategic Management Journal, 24(10), 161.

37. Mulili, B.M. \& Wong, P. (2011). Corporate Governance Practices in Developing Countries: The Case for Kenya. International Journal of Business Administration, Vol. 2 (1):14-27.

38. Murage, H.N. (2008). The Relationship Between Corporate Governance and Financial Performance of Parastatals in Kenya. (Unpublished MBA Project), School of Business, University of Nairobi, Kenya.

39. Njoka, P.G. (2008). The Relationship Between Corporate Governance Practices and Financial Performance of Property Management Companies in Kenya. (Unpublished MBA Project), School of Business, University of Nairobi, Kenya.

40. Nyaga, A. (2007). Corporate Governance and Performance of Manufacturing Firms Listed in the Nairobi Stock Exchange. (Unpublished MBA Project), School of Business, University of Nairobi, Kenya. 
41. Odondi, H.A. (2009). The Impact of Corporate Governance on the Financial Performance of Community Based Organizations in Kibera. (Unpublished MBA Project), School of Business, University of Nairobi, Kenya.

42. Ombayo, J.O. (1999). The Effect of Corporate Governance on Financial Performance: A Case Study of Companies Listed at the NSE. (Unpublished MBA Project), School of Business, University of Nairobi, Kenya.

43. Ondiek, G. O., Kisombe, M. S. and Magutu, P. O. (2013). Lean Operations Tools and Techniques Used in the Sugar Sector in Kenya, African Journal of Business and Management, 3, 83-97.

44. Ongore, V. O. \& K'Obonyo, P. O. (2011). Effects of Selected Corporate Governance Characteristics on Firm Performance: Empirical Evidence from Kenya. International Journal of Economics and Financial Issues, .1(3), 99-122.

45. Onzare, W.N. (2008). Relationship Between Corporate Governance and Financial Performance of Small and Medium Enterprise in Nairobi. (Unpublished MBA Project), School of Business, University of Nairobi, Kenya.

46. Onyango, L. (2009. Governance Structures of SNV in Implementing its Profits. (Unpublished MBA Project), School of Business, University of Nairobi, Kenya.

47. Ophelie, R. (2006).Bio-Fuels for Transport in Developing Countries: A Case Study of Kenya UNEP, Nairobi, Kenya.

48. Oso, W. Y. \& Onen, D. (2009). A General Guide to Writing Research Proposals and Reports (Rev. ed). Nairobi: Jomo Kenyatta Foundation.

49. Pfeffer,J. \& Salancik, G.R. (1978). The External Control of Organizations: A Resource Dependence Perspective. Harper and Row, New York, NY.

50. Private Sector Corporate Governance Trust (PSCGT) (1999). Principles for Corporate Governance in Kenya: A Sample Code of Best Practices for Corporate Governance, Nairobi.

51. Reddy, K., Locke, S., and Scrimgeour, F. (2010). The Efficacy of Principle-Based Corporate Governance Practice and Firm Performance: An Empirical Investigation. International Journal of Managerial Finance, 6(3), 190-201.

52. Ross, S. (1973). The Economic Theory of Agency: The Principal's Problem. American Economic Review, 63(2), 134-139.

53. Shleifer, A. \& Vishny, R. (1997), A Survey of Corporate Governance. Journal of Finance, 52, 721-733.

54. Vafeas, N. (1999). Board Meeting Frequency and Firm Performance. Journal of Financial Economics, 53, 113-122. 
55. Thakkar, J., Deshmukh, S. G., Gupta, A. D.. \& Ravi, S. (2007). Development of a Balanced Scorecard: An Integrated Approach of Interpretive Structural Modeling (ISM) and Analytic Network Process (ANP), .International Journal of Productivity and Performance Management, 56(1), 25-51.

56. Van den Berghe, L. \& Levrau, A. (2004). Evaluating Boards of Directors: What Constitutes Good Governance? Corporate Governance: An International Review, 12, 461-478. 